\title{
EFFECTS OF NATURAL ANTIOXIDANTS ON COLOUR STABILITY, LIPID OXIDATION AND METMYOGLOBIN REDUCING ACTIVITY IN RAW BEEF PATTIES
}

\author{
Fang Liu, Qian Xu, Ruitong Dai, Yuanying Ni ${ }^{凶}$ \\ College of Food Science and Nutritional Engineering, China Agricultural University \\ 17 Qinghua East Road, Beijing, China
}

\begin{abstract}
Background. Minced meats undergo oxidative changes and develop rancidity more quickly than intact muscle since grinding exposes more of the muscle surface to air and microbial contamination. Due to concerns about toxicological safety of synthetic antioxidants, recent studies have put more focus on natural antioxidant compounds derived from food components.

Material and methods. The effects of four natural antioxidants (vitamin E, carnosine, grape seed extract and tea catechins) on oxidative processes and metmyoglobin reducing activity in raw beef patties during refrigerated $\left(4^{\circ} \mathrm{C}\right)$ storage were investigated and the results were compared with butylated hydroxyanisole treatment patties. The correlation of lipid oxidation, colour and metmyoglobin reducing activity of beef patties were also studied.

Results. Samples treated with carnosine had the highest redness values on the eighth day. Tea catechins, vitamin $\mathrm{E}$ and grape seed extract showed higher protective effect against lipid oxidation than carnosine. Metmyoglobin reducing activity increased greatly in all samples during the storage. Significant correlation between redness value and lipid oxidation was demonstrated, while a weak correlation between metmyoglobin reducing activity and any other parameters was shown.
\end{abstract}

Key words: beef patties, natural antioxidation, colour, lipid oxidation, metmyoglobin reducing activity

\section{INTRODUCTION}

Obtaining a stable red or purple colour of ground beef is a challenge, since the color is influenced by a number of factors. Lipid oxidation and discoloration are major problems for meat products during storage and distribution. Oxidative deterioration in any type of meat manifests in form of discoloration, development of off flavour, formation of toxic compounds, poor shelf life, nutrient and drip losses, respectively (Falowo et al., 2014; Shah et al., 2014). Minced meats undergo oxidative changes and develop rancidity more quickly than intact muscle since grinding exposes more of the muscle surface to air and microbial contamination (Alp and Aksu, 2010). Antioxidants are regarded as compounds that are able to delay, retard

\footnotetext{
*This research was financially supported by the National Science and Technology Support Plan of the Chinese Ministry of Education (Project No. 2012BAD31B00).
} 
or prevent oxidation processes (Lorenzo et al., 2014). Adding of antioxidants is one of the typical methods to inhibit oxidation reactions in meat products (Kim et al., 2013).

The potential of synthetic antioxidants causing toxicological effects has created demand for natural antioxidants by consumers and the meat industry (Falowo et al., 2014). Recent studies have put more focus on natural antioxidant compounds derived from food components, such as vitamin E, carnosine, grape seed extracts, and tea catechins.

Vitamin E, especially as $\alpha$-tocopherol, is widely used as an antioxidant, reducing lipid oxidation, drip losses and providing colour stability as consequence of the close relation between oxidation of lipids and oxymioglobin in muscle tissues (Ripoll et al., 2011). Carnosine is a compound of naturally-occurring dipeptide that synthesized by the carnosine synthetase from $\beta$-alanine and L-histidine. Carnosine inhibits the formation of thiobar-bituric acid reactive substances in various oxidative model systems. Because of its antioxidant properties, carnosine has been suggested as a useful natural food antioxidant. Grape seed extracts contain a number of polyphenols including procyanidins and proanthocyanidins and are powerful free radical scavengers. It has been investigated in vitro, such as mutton slices (Falowo et al., 2014), cooked beef (Ahna et al., 2007) and pork patties (Lorenzo et al., 2014) and burgers (Garrido et al., 2011). Tea catechins are polyphenolic antioxidants which possess a range of health promoting properties. Tea catechins have demonstrated significant antioxidant, anti-carcinogenic, anti-mutagenic properties in numerous human, animal and in vitro studies. Tea polyphenols are metal chelating agents and also act on free radicals, since their benzene rings, inhibit chain reactions during lipid oxidation (Tang et al., 2002).

The objectives of this study were to investigate (I) the effect of vitamin E, carnosine, grape seed extracts and tea catechins in preventing lipid oxidation, myoglobin oxidation, and the loss of colour, in raw beef patties during 8 days of storage under $4^{\circ} \mathrm{C}$. (II) The correlation of metmyoglobin reducing activity, meat colour stability and lipid oxidation.

\section{MATERIAL AND METHODS}

\section{Reagents}

L-carnosine $\left(\mathrm{C}_{9} \mathrm{H}_{14} \mathrm{~N}_{4} \mathrm{O}_{3}\right)$, tea catechins (polyphenols $\mathrm{P}$ $98 \%$, catechins P 90\%), grape seed extracts, vitamin E and BHA were all purchased from Qinghua Kechuang Food Additives Co. Ltd. (Beijing, China). NADH and equine Myoglobin were obtained from Sigma (St. Louis, USA). All other chemicals and solvents used were of analytical grade and purchased from Lanyi Chemical Articles Co. Ltd. (Beijing, China).

\section{Sample preparation}

Beef strip loins (Longissimus dorsi muscle, LD) were obtained at $48 \mathrm{~h}$ post mortem. The animals were stunned and slaughtered in a commercial plant following the industry practices. After dressing, the carcasses were held at $4 \pm 1^{\circ} \mathrm{C}$ for $48 \mathrm{~h}$. The average ultimate $\mathrm{pH}$ was $5.70 \pm 0.05$.

Beef LD muscles were chopped into small pieces after removal of visible fat and connective tissues. Chopped meat samples $(180 \mathrm{~g})$ were ground using a food processor (CombinMax600, China). Meat samples were sprinkled with the appropriate antioxidants during grinding (tea catechins, vitamin E, grape seed extract and carnosine at the concentration of $0.3 \mathrm{~g} / \mathrm{kg}$ meat, while BHA of $0.03 \mathrm{~g} / \mathrm{kg}$ meat and control samples with no added antioxidant ingredients. Meat patties were formed using a meat former and stored at $4^{\circ} \mathrm{C}$. Two samples were taken from each group at 0 , 2, 4, 6 and 8 days of storage. All analyses were performed in triplicate.

\section{TBARS values}

Lipid oxidation was assessed in beef patties during refrigerated $\left(4 \pm 1^{\circ} \mathrm{C}\right)$ storage. Thiobarbituric acidreactive substances (TBARS) assay was performed as described by Liu et al. (2010) with little modification. Pattie samples $(10 \mathrm{~g})$ were mixed with $45 \mathrm{ml}$ of stock solution ( $25 \mathrm{ml} \mathrm{20 \%} \mathrm{TCA} \mathrm{-} 20 \mathrm{ml}$ water) and homogenized for $30 \mathrm{~s}$ with a superfine homogenizer (F6-10, Fluko, Shanghai, China) and centrifuged at $1000 \mathrm{~g}$ for $20 \mathrm{~min}$ at $4^{\circ} \mathrm{C}$. The supernatant was filtered through Whatman No. 1 filter paper. The solution ( $3 \mathrm{ml}$ superna$\operatorname{tant}-3 \mathrm{ml} 0.02 \mathrm{M} \mathrm{TBA}$ ) heated in a boiling water bath for $30 \mathrm{~min}$ to develop the pink colour. Samples were cooled under running tap water, centrifuged at $4500 \mathrm{~g}$ 
for $25 \mathrm{~min}$ and the absorbance of the supernatant was measured at $532 \mathrm{~nm}$ using a Unicam UV4 spectrometer (Unicam Ltd., China). TBA number was calculated as mg malondialdehyde/kg sample following the formula:

$$
\text { TBA value, } \mathrm{mg} / 100 \mathrm{~g}=\left(A_{532}-A_{600}\right) / 155 \cdot(1 / 10) .
$$

\section{Percentage of metmyoglobin}

Pattie samples $(5 \mathrm{~g})$ were homogenized in $25 \mathrm{ml}$ icecold $40 \mathrm{mM}$ phosphate buffer ( $\mathrm{pH}$ 6.8) for $10 \mathrm{~s}$ using a superfine homogenizer (F6-10, Fluko, Shanghai, China; $13,500 \mathrm{rpm})$. The homogenate was allowed to stand for $1 \mathrm{~h}$ at $4^{\circ} \mathrm{C}$ and centrifuged at $4500 \mathrm{~g}$ for $30 \mathrm{~min}$ at $4^{\circ} \mathrm{C}$. The supernatant was filtered through Whatman No. 1 filter paper and the absorbance was measured at 572, 565, 545 and $525 \mathrm{~nm}$ using a Unicam UV4 spectrometer (Unicam Ltd., China). The percentage of Metmyoglobin (MetMb\%), was determined as described by Krzywicki (1982) using the formula:

$$
\begin{aligned}
\mathrm{MetMb} \% & =\left\{-2.514\left(A_{572} / A_{525}\right)+0.777\left(A_{565} / A_{525}\right)+\right. \\
& \left.+0.8\left(A_{545} / A_{525}\right)+1.098\right\} \cdot 100
\end{aligned}
$$

\section{Metmyoglobin-reducing activity}

Metmyoglobin reductase was extracted from freezestored samples $\left(-80^{\circ} \mathrm{C}\right)$ as described by Mikkelsen et al. (1999). A $12 \mathrm{~g}$ sample and $20 \mathrm{ml}$ phosphate buffer, $\mathrm{pH} 7.0$, was homogenized for $30 \mathrm{~s}$ with a Polytron PT 3100 (Polytron, Littau, China) at 13,500 rpm. The homogenate was centrifuged at $35,000 \mathrm{~g}$ for $30 \mathrm{~min}$ at $4{ }^{\circ} \mathrm{C}$ and the supernatant filtered through Whatman No. 1 filter paper to remove fat. Oxy-hemoproteins were oxidized with excess $\mathrm{K}_{3} \mathrm{Fe}(\mathrm{CN})_{6}$ and the solution was dialyzed (14,000 MW cut-off) against $2.0 \mathrm{mM}$ phosphate buffer $\mathrm{pH} 7.0$ at $4^{\circ} \mathrm{C}$. The solution was centrifuged at $15,000 \mathrm{~g}$ for $20 \mathrm{~min}$ at $4^{\circ} \mathrm{C}$ and the volume of the supernatant adjusted to $20 \mathrm{ml}$ with $2.0 \mathrm{mM}$ phosphate buffer $\mathrm{pH}$ 7.0.

Metmyoglobin-reducing activity was determined as described by Mikkelsen et al. (1999) using a Unicam UV4 spectrometer (Unicam Ltd., China). The standard assay mixture contained $0.1 \mathrm{ml} 5 \mathrm{mM}$ EDTA, $0.1 \mathrm{ml} 50 \mathrm{mM}$ phosphate buffer ( $\mathrm{pH} 7.0), 0.1 \mathrm{ml} 3.0$ $\mathrm{mM} \mathrm{K}_{4} \mathrm{Fe}(\mathrm{CN})_{6}, 0.1 \mathrm{ml}$ water, $0.2 \mathrm{ml} 0.75 \mathrm{mM} \mathrm{Mb}$ $\mathrm{Fe}(\mathrm{III})$ in $2.0 \mathrm{mM}$ phosphate buffer (pH 7.0), $0.3 \mathrm{ml}$ muscle extract, and $0.1 \mathrm{ml} 2.0 \mathrm{mM}$ NADH. The final
$\mathrm{pH}$ of the assay mixture was 6.4 and the assay was carried out at $25^{\circ} \mathrm{C}$. The reaction was initiated by adding $\mathrm{NADH}$ and was determined by following the change in absorbance at $580 \mathrm{~nm}$. Blanks contained all the additions except NADH which was replaced by water. Metmyoglobin-reducing activity was measured in units of $\min ^{-1}$ and is calculated as MetMb-reducing activity $=\Delta A_{580} / \Delta t . \Delta A_{580}$ is the change in absorbance at $580 \mathrm{~nm}$ per min during the period where the rate of change is linear with time; $\Delta t$ is the time ( $\mathrm{min}$ ) between two measurements of the absorbance.

\section{Colour}

Colour of ground beef patties was determined using a reflectance colorimeter (WSC-S, China) and expressed as CIE Lab $a^{*}$ (redness). Three replicate measurements were taken for each sample directly after blending and, subsequently, every $24 \mathrm{~h}$ until the meat was visually unacceptable.

\section{STATISTICAL AND DATA ANALYSIS}

Data analysis was done with the ANOVA function in the Statistical Program for Social Sciences (SPSS 12.0, Chicago, IL, USA) software, and significant differences were determined with a Duncan multiple range test. Relationships among measurement variables were studied using standard correlation, $r$ values being the correlation factor.

\section{RESULTS AND DISCUSSION}

\section{Colour}

Redness $\left(a^{*}\right)$ values decreased $(p<0.05)$ progressively during 8 days of storage (Table 1). Antioxidant treatments significantly $(p<0.05)$ slowed the patties discoloration. Treatment with grape seed extract and carnosine significantly retarded discoloration $(p<0.05)$ compared with other treatments. The effectiveness of the antioxidants in preserving the redness value was in the following order: carnosine $>$ grape seed extract $>$ vitamin $\mathrm{E}>$ tea catechins $>$ BHA.

Although many factors can influence the stability of meat colour, the oxidation of Myoglobin by free radical lipid peroxidation products is predominant. The biochemistry of myoglobin and its interactions with small biomolecules in a complex muscle food 
Liu, F., Xu, Q., Dai, R., Ni, Y. (2015). Effects of natural antioxidants on colour stability, lipid oxidation and metmyoglobin reducing activity in raw beef patties. Acta Sci. Pol. Technol. Aliment., 14(1), 37-44. DOI: 10.17306/J.AFS.2015.1.4

Table 1. Effect of antioxidants on redness $a^{*}$ value of raw beef patties during refrigerated storage $\left(4 \pm 1^{\circ} \mathrm{C}\right)$

\begin{tabular}{|c|c|c|c|c|c|c|}
\hline $\begin{array}{c}\text { Time } \\
\text { day }\end{array}$ & Control & BHA & $\mathrm{TC}$ & VE & GSE & $\mathrm{CR}$ \\
\hline 0 & $27.14 \pm 0.24 \mathrm{xa}$ & $26.66 \pm 0.666 x \mathrm{xa}$ & $26.99 \pm 0.65 x a$ & $27.3 \pm 0.53 x a$ & $27.21 \pm 0.31 \mathrm{xa}$ & $26.667 \pm 0.568 \mathrm{xa}$ \\
\hline 2 & $24.28 \pm 0.21 \mathrm{ybe}$ & $25.03 \pm 0.58 \mathrm{ye}$ & $21.56 \pm 1.22 \mathrm{yc}$ & $21.49 \pm 0.44 \mathrm{yc}$ & $20.9 \pm 0.14 y \mathrm{c}$ & $22.43 \pm 0.41 \mathrm{ydc}$ \\
\hline 4 & $17.45 \pm 0.36 \mathrm{zc}$ & $20.05 \pm 0.94 \mathrm{za}$ & $17.01 \pm 0.35 \mathrm{zc}$ & $19.71 \pm 0.46 \mathrm{za}$ & $18.58 \pm 0.49 \mathrm{zb}$ & $19.74 \pm 0.11 \mathrm{za}$ \\
\hline 6 & $15.87 \pm 0.31 \mathrm{hb}$ & $16.21 \pm 0.22 \mathrm{hb}$ & $17.18 \pm 0.11 \mathrm{zb}$ & $18.57 \pm 0.33 \mathrm{hb}$ & $26.002 \pm 0.744 \mathrm{ha}$ & $26.928 \pm 0.411 \mathrm{xa}$ \\
\hline 8 & $14.986 \pm 0.277$ we & $15.99 \pm 0.65 \mathrm{hd}$ & $16.27 \pm 0.37 \mathrm{zd}$ & $20.173 \pm 0.466 \mathrm{zc}$ & $27.293 \pm 0.0929 \mathrm{xb}$ & $28.893 \pm 0.178 \mathrm{ha}$ \\
\hline
\end{tabular}

$\mathrm{x}-\mathrm{w}-$ means in same row with the same letter are not significantly different at $p<0.05$.

a-e - means in same column with the same letter are not significantly different at $p<0.05$.

TC - tea catechins, VE - vitamin E, GSE - grape seed extract, CR - carnosine.

matrix govern the colour of meat, and numerous other factors affect the color stability of meat from livestock and poultry (Suman et al., 2014). The low temperature $\left(4 \pm 1^{\circ} \mathrm{C}\right)$ and effect of antioxidation during storage most likely slowed the deterioration of the colour observed in these patties.

Mielnik et al. (2006) demonstrated that grape seed extract could marginally increase redness values of raw pork patties with increasing concentration which is similar with our research. This colour stabilizing effect is due indirectly to delayed oxidation of $\mathrm{MbO}_{2}$ via direct inhibition of lipid oxidation. Carnosine exerted significant efficacy in maintaining an acceptable visual red colour during storage of ground beef and raw patties. Badr et al. (2007) reported that $0.5 \%$ or $1 \%$ carnosine exerted significant efficacy in maintaining an acceptable visual red colour post-irradiation and during storage of ground beef and raw patties. In the present study, carnosine exhibited a significantly higher $(p<0.05)$ redness value than the control. Carnosine may be involved in the regeneration of NADH.

\section{Percentage of metmyoglobin}

The storage time and antioxidant treatment both affected the MetMb\%. MetMb\% increased $(p<0.05)$ progressively during 6 days of storage (Table 2 ). There were significant $(p<0.05)$ differences in the content of MetMb of all samples, and beef patties treated with antioxidants had lower MetMb\% than control groups after 8 days of storage. The data suggest that the efficiency of the examined antioxidations in inhibiting myoglobin and/or oxymyoglobin oxidation is in the following order: carnosin $>$ grape seed extract $>$ vitamin $\mathrm{E}>$ tea catechins $>$ BHA.

Table 2. Effect of antioxidants on MetMb\% in raw beef patties during refrigerated storage $\left(4 \pm 1^{\circ} \mathrm{C}\right)$

\begin{tabular}{|c|c|c|c|c|c|c|}
\hline $\begin{array}{l}\text { Time } \\
\text { day }\end{array}$ & Control & BHA & $\mathrm{TC}$ & VE & GSE & $\mathrm{CR}$ \\
\hline 0 & $3.915 \pm 0.0495 \mathrm{xa}$ & $5.910 \pm 0.184 \mathrm{xb}$ & $7.845 \pm 1$ & $8.005 \pm 0.785 \mathrm{xc}$ & $8.580 \pm 0.311 \mathrm{xc}$ & $6.095 \pm 0.163 \mathrm{xb}$ \\
\hline 2 & $20.050 \pm 0.269$ yа & $17.445 \pm 0.148 \mathrm{yb}$ & $20.365 \pm 0.233$ уа & $20.685 \pm 0.0212$ уас & $21.635 \pm 0.530 \mathrm{yc}$ & $17.700 \pm 0.990 y b$ \\
\hline 4 & $27.000 \pm 0.0283 \mathrm{za}$ & $26.765 \pm 0.0636 \mathrm{za}$ & $28.565 \pm 0.629 \mathrm{zb}$ & $31.935 \pm 0.0919 \mathrm{zb}$ & $24.495 \pm 0.0212 \mathrm{zc}$ & $24.695 \pm .106 \mathrm{zc}$ \\
\hline 6 & $38.065 \pm 1.704 \mathrm{ha}$ & $32.355 \pm 0.0778 \mathrm{hb}$ & $36.205 \pm 0.219 \mathrm{hc}$ & $32.745 \pm 0.361 \mathrm{zhb}$ & $34.540 \pm 0.0141 \mathrm{hc}$ & $35.605 \pm 0.00707 \mathrm{hc}$ \\
\hline 8 & $38.905 \pm 0.0354 \mathrm{ha}$ & $35.830 \pm 0.255 \mathrm{wb}$ & $36.455 \pm 0.459 \mathrm{hc}$ & $33.260 \pm 0.141 \mathrm{hd}$ & $27.345 \pm 0.0353 \mathrm{we}$ & $24.695 \pm 0.0495 \mathrm{zf}$ \\
\hline
\end{tabular}

Means in same row with the same letter (x-w) are not significantly different at $p<0.05$.

Means in same column with the same letter (a-e) are not significantly different at $p<0.05$. 
In agreement with the present results, retarded the formation of the MetMb in beef due to the effect of carnosine, was also reported by other researchers. Das et al. (2006) observed that meat samples containing $1.0 \%$ and $1.5 \%$ carnosine significantly inhibited Met$\mathrm{Mb}$ formation. However, Bekhit et al. (2003) found that carnosine accelerated the accumulation of MetMb and after 6 days of storage, MetMb\% was $50 \%$ higher than that of the control group. This might be due to the different concentration of carnosine used in the experiment.

\section{Lipid oxidation}

Lipid oxidation levels increased in all beef patties as storage time increased (Table 3). Antioxidants treated patties showed more lipid stability than control groups, but there were no significant $(p<0.05)$ differences among those antioxidants-treated patties. On the $8^{\text {th }}$ day, the inhibition rate $(\Delta$ inhibition $(\%))$ of lipid oxidation of beef patties treated with various natural antioxidants was $34.03 \%, 20.0 \%, 14.30 \%, 11.60 \%$ and $13.40 \%$ for BHA, tea catechins, vitamin E, grape seed extract and carnosine, respectively (Table 3 ). It is also interesting to point out that tea catechins had a similar antioxidation effect with BHA on the $8^{\text {th }}$ day.

Bekhit et al. (2003) found carnosine-treated meat exhibited higher TBARS values compared to that of control group. But Djenane et al. (2004) found that carnosine exerted a significant $(p<0.05)$ inhibition effect on TBARS formation. And Badr et al. (2007) found that addition of carnosine significantly $(P<$ 0.05 ) reduced the oxidative processes and MetMb formation (proportionally to the used concentration) in samples post-irradiation and during storage of ground beef and raw patties. The different results on the effect of carnosine in lipid oxidation might be explained by the different species of materials used in the research.

Brannan and Mah (2007) have reported that grape seed extract was very effective inhibitor of primary and secondary oxidation products in various muscle systems even at concentrations as low as $0.1 \%$. As discussed earlier, tea catechins $(300 \mathrm{mg} / \mathrm{kg}$ meat $)$ were also reported to be more effective compared to vitamin E (300 mg $\alpha$-tocopherol/kg meat) in retardation of lipid oxidation in cooked beef and chicken meat and in raw red meat, poultry and fish muscle (Tang et al., 2001a). Phenolic -compounds interrupt the propagation of the free radical auto oxidation chain by contributing a hydrogen atom from a phenolic hydroxyl group $(-\mathrm{OH})$, with the formation of a relatively stable free radical that does not initiate or propagate further oxidation processes (Falowo et al., 2014).

\section{Metmyoglobin reducing activity (MRA)}

The results of MRA are shown in Table 4. Results clearly demonstrated that after 7 days of storage, MRA

Table 3. Effect of antioxidants on TBARS value (mg MDA/kg meat) in raw beef patties during refrigerated storage $\left(4 \pm 1^{\circ} \mathrm{C}\right)$

\begin{tabular}{|c|c|c|c|c|c|c|}
\hline $\begin{array}{c}\text { Time } \\
\text { day }\end{array}$ & Control & BHA & $\mathrm{TC}$ & VE & GSE & $\mathrm{CR}$ \\
\hline 0 & $0.162 \pm 0.00778 \mathrm{xa}$ & $0.165 \pm 0.00707 \mathrm{xa}$ & $0.149 \pm 0.0283 \times \mathrm{xa}$ & $0.161 \pm 0.0113 \mathrm{xa}$ & $0.156 \pm 0.00424 \mathrm{xa}$ & $0.158 \pm 0.00636 \mathrm{xa}$ \\
\hline 2 & $0.202 \pm 0.0184$ ya & $0.159 \pm 0.00141 \mathrm{xc}$ & $0.155 \pm 0.00141 \mathrm{xc}$ & $0.175 \pm 0.00354 \mathrm{xbc}$ & $0.168 \pm 0.0283 y b c$ & $0.188 \pm 0.00212 \mathrm{yab}$ \\
\hline 4 & $0.232 \pm 0.00212 \mathrm{ya}$ & $0.177 \pm 0.00283 \mathrm{xc}$ & $0.213 \pm 0.0109 y b$ & $0.22 \pm 0.0141 \mathrm{yab}$ & $0.224 \pm 0.00354 \mathrm{zab}$ & $0.216 \pm 0.0307 \mathrm{zb}$ \\
\hline 6 & $0.318 \pm 0.0197 \mathrm{za}$ & $0.212 \pm 0.0134 \mathrm{yd}$ & $0.249 \pm 0.0990 \mathrm{zc}$ & $0.268 \pm 0.0148 \mathrm{zbc}$ & $0.288 \pm 0.0144 \mathrm{hab}$ & $0.265 \pm 0.00354 \mathrm{hbc}$ \\
\hline 8 & $0.335 \pm 0.00141 \mathrm{za}$ & $0.221 \pm 0.00636 \mathrm{yd}$ & $0.268 \pm 0.0134 \mathrm{zc}$ & $0.287 \pm 0.00495 \mathrm{zbc}$ & $0.296 \pm 0.00212 \mathrm{hab}$ & $0.290 \pm 0.0156 \mathrm{wbc}$ \\
\hline $\begin{array}{c}\Delta \text { Inhi- } \\
\text { bition } \\
\%\end{array}$ & - & 34.03 & 20.00 & 14.30 & 11.60 & 13.40 \\
\hline
\end{tabular}

$\mathrm{X}-\mathrm{w}-$ means in same row with the same letter are not significantly different at $p<0.05$. a-e - means in same column with the same letter are not significantly different at $p<0.05$. $\Delta$ Inhibition, $\%=$ TBARS (control) ${ }_{8}-$ TBARS (antioxidant) ${ }_{8} /$ TBARS $_{8}$ (control) $\cdot 100$. 
Liu, F., Xu, Q., Dai, R., Ni, Y. (2015). Effects of natural antioxidants on colour stability, lipid oxidation and metmyoglobin reducing activity in raw beef patties. Acta Sci. Pol. Technol. Aliment., 14(1), 37-44. DOI: 10.17306/J.AFS.2015.1.4

Table 4. Effect of antioxidants on MRA $\left(\mathrm{nmol} \cdot \mathrm{min}^{-1} \cdot \mathrm{g}^{-1}\right)$ in raw beef patties during refrigerated storage $\left(4 \pm 1^{\circ} \mathrm{C}\right)$

\begin{tabular}{|c|c|c|c|c|c|c|}
\hline $\begin{array}{l}\text { Time } \\
\text { day }\end{array}$ & Control & BHA & $\mathrm{TC}$ & $\mathrm{VE}$ & GSE & $\mathrm{CR}$ \\
\hline 0 & $0.198 \pm 0.00849 x a$ & $0.195 \pm 0.0127 x a$ & $0.184 \pm 0.00849 x a$ & $0.177 \pm 0.00424 \mathrm{xa}$ & $0.186 \pm 0.00424 \mathrm{xa}$ & $0.180 \pm 0.00846 \mathrm{xa}$ \\
\hline 2 & $0.207 \pm 0.0212 \mathrm{yc}$ & $0.225 \pm 0.0212 \mathrm{xd}$ & $0.282 \pm 0.0594$ уа & $0.309 \pm 0.00415 \mathrm{ybc}$ & $0.282 \pm 0.00848 \mathrm{yc}$ & $0.291 \pm 0.0297 \mathrm{ybc}$ \\
\hline 4 & $0.306 \pm 0.00101 \mathrm{zb}$ & $0.324 \pm 0.00849 \mathrm{yab}$ & $0.354 \pm 0.0170 y z a$ & $0.345 \pm 0.0212 \mathrm{yza}$ & $0.321 \pm 0.00424 \mathrm{zab}$ & $0.303 \pm 0.0205 y b$ \\
\hline 6 & $0.333 \pm 0.00424 \mathrm{zhb}$ & $0.351 \pm 0.0127 y z b$ & $0.372 \pm 0.00849 \mathrm{za}$ & $0.357 \pm 0.0211 \mathrm{yzb}$ & $0.339 \pm 0.00425 \mathrm{zb}$ & $0.348 \pm 0.0424 \mathrm{yb}$ \\
\hline 8 & $0.354 \pm 0.00848 \mathrm{hb}$ & $0.360 \pm 0.0170 \mathrm{zb}$ & $0.375 \pm 0.0127 \mathrm{zb}$ & $0.381 \pm 0.0297 \mathrm{zab}$ & $0.405 \pm 0.0212 \mathrm{ha}$ & $0.381 \pm 0.0127 \mathrm{zab}$ \\
\hline
\end{tabular}

$\mathrm{X}-\mathrm{w}-$ means in same row with the same letter are not significantly different at $p<0.05$.

a-e - means in same column with the same letter are not significantly different at $p<0.05$.

were significantly increased $(p<0.05)$ with all the patties than the first day. A greater increase was observed with carnosine, tea catechins, vitamin $\mathrm{E}$ and grape seed extract treatments compared to BHA.

Bekhit et al. (2001) also observed a 20\% increase in MetMb reducing activity in ovine muscle after vacuum storage for 6 weeks, supporting the results in this research. On the other hand, Pong et al. (2000a) also found Tuna muscle MetMb reducing activity decreased to less than $20 \%$ of its original activity after 3 days of cold storage.

While the techniques and assay conditions used in determining MetMb reducing activity might explain some of the different results from different researchers, the controversy regarding the effect of storage time on $\mathrm{MetMb}$ reducing activity cannot be attributed solely to the methodology employed (Bekhit and Faustman, 2005). There is still a need to understand the factors which influence the activities of MetMb reductase.

\section{The correlation between TBARS values, $a^{*}$ and $M$ MetMb\%}

There was a significant $(p<0.01)$ positive correlation $(r=0.880)$ between lipid oxidation and MetMb\%, while a significant $(p<0.01)$ negative correlation $(r=-0.886)$ between MetMb\% and $a^{*}$ (Table 5). To predict the TBARS value, a regression equation $(Y=-273.65 X-30.288)$ was established, where $Y=$ MetMb $\%$ and $X=$ TBARS value or $(Y=-98.533 X+$ 40.988), where $Y=a^{*}$ and $X=$ TBARS value (Fig. 1).

Das et al. (2006) also found that MetMb\% showed significant $(p<0.01)$ positive correlation $(r=0.66)$ with TBARS values. The reason behind such positive correlation may be that lipid oxidation produces peroxide material and free radicals which promote the pigment oxidation, resulting in meat discoloration (Cheng et al., 2007). On the other hand, pigment oxidation produces iron ion and promotes lipid oxidation (Grunwald and Richards, 2006). But not all studies that have measured lipid oxidation and myolobin oxidation in meat have produced results demonstrating that the two processes are linked (Faustman et al., 2010). Hayes et al. (2009) found that sesamol addition to porcine and bovine meat systems led to decreased lipid oxidation but enhanced OxyMb oxidation; addition of ellagic acid and olive leaf extract led to decreases in both oxidative processes. Faustman et al. (2010) found that atmospheres containing very high or very low concentrations of oxygen provide conditions in which the oxidative interaction between lipid and myoglobin is not tightly linked.

Table 5. Correlation coefficients ( $r$-value) of MRA, Met$\mathrm{Mb}(\%)$, TBARS value and $a *$ in raw beef patties as affected by application of different antioxidants during refrigerated storage $\left(4 \pm 1^{\circ} \mathrm{C}\right)$

\begin{tabular}{lclll}
\hline & MetMb\% & \multicolumn{1}{c}{$a^{*}$} & TBARS & MRA \\
\hline MetMb\% & 1 & $-.886^{* *}$ & $.880^{* *}$ & -0.27 \\
$a^{*}$ & $-.886^{* *}$ & 1 & $-.685^{* *}$ & 0.17 \\
TBARS & $.880^{* *}$ & $-.685^{* *}$ & 1 & -0.03 \\
MRA & -0.27 & 0.17 & -0.03 & 1 \\
\hline
\end{tabular}

$* p<0.05, * * p<0.01$. 


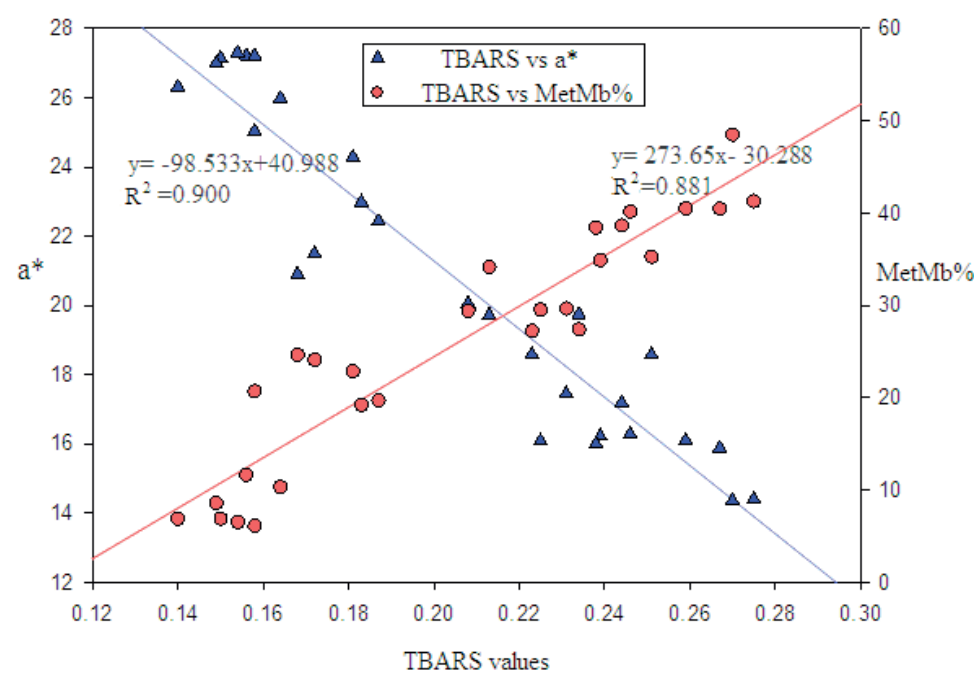

Fig. 1. Relationship of TBARS values, MetMb\% and $a^{*}$ in beef meat patties pre-blended with different antioxidants during refrigerated storage $\left(4 \pm 1^{\circ} \mathrm{C}\right)$

\section{The correlation between TBARS values, MRA and $a^{*}$}

A weaker $(p>0.05)$ correlation was found between MRA and TBARS values $(r=-0.03)$, and there was also a weak correlation between MRA and $a^{*}(r=0.17)$.

Few studies have demonstrated an association between MRA in meat and its colour stability. Bekhit and Faustman (2005) believed that the biochemical $\mathrm{MetMb}$ reducing system in post-mortem muscle was the most important factor regulating colour but found no significant correlation between MRA and meat discoloration. Bekhit et al. (2001) also found no correlation between metmyoglobin reducing activity and colour stability parameters in lamb loin meat, whereas factors influencing oxygen diffusion and consumption and the auto- oxidation of myoglobin have been shown to impact lamb meat colour during display (Jose, 2011).

The oxidation of $\mathrm{Mb}$ could generating free radicals that promote lipid oxidation and leads to meat discoloration, since total MRA (sarcoplasmic and myofibrillar) was highly correlated with lipid oxidation (Bekhit and Faustman, 2005). So a hypothesis could be made from the present studies that antioxidants protected the red colour of fresh meat by protecting enzyme-based MetMb reducing systems from damaging by lipid oxidation products.

\section{CONCLUSION}

It was concluded that addition of antioxidants to beef meat patties inhibited lipid oxidation and retarded the formation of metmyoglobin. Lipid oxidation was positively and strongly correlated $(r=0.880)$ with MetMb\% and negatively $(r=0.886)$ with redness values. Tea catechins and grape seed extract effectively retard the oxidative processes in raw beef patties and their antioxidant ability is superior to carnosine. Tea catechins, grape seed extract and carnosine had a better protection effect on colour stability than vitamin $\mathrm{E}$. The present approach is expected to provide a crucial guideline to use various antioxidants for retardation of oxidation of other meat products.

\section{REFERENCES}

Ahna, J., Grun, I. U., Mustaphab, A. (2007). Effects of plant extracts on microbial growth, color change, and lipid oxidation in cooked beef. Food Microbiol., 24, 7-14.

Alp, E., Aksu, M. İ. (2010). Effects of water extract of Urtica dioica $\mathrm{L}$. and modified atmosphere packaging on the shelf life of ground beef. Meat Sci., 86, 468-473.

Badr, H. M. (2007). Antioxidative activity of carnosine in gamma irradiated ground beef and beef patties. Food Chem., 104, 2, 665-679. 
Liu, F., Xu, Q., Dai, R., Ni, Y. (2015). Effects of natural antioxidants on colour stability, lipid oxidation and metmyoglobin reducing activity in raw beef patties. Acta Sci. Pol. Technol. Aliment., 14(1), 37-44. DOI: 10.17306/J.AFS.2015.1.4

Bekhik, A. E. D., Geesink, G. H., Morton, J. D., Bickerstaffe, R. (2001). Metmyoglobin reducing activity and color stability of ovine longissimus muscle. Meat Sci., 57, 427-435.

Bekhik, A. E. D., Geesink, G. H., Ilian, M. A., Morton, J. D., Bickerstaffe, R. (2003). The effects of natural antioxidants on oxidative processes and metmyoglobin reducing activity in beef patties. Food Chem., 81, 2, 175-187.

Bekhit, A. E. D., Faustman, C. (2005). Metmyoglobin reducing activity. Meat Sci., 71, 407-439.

Brannan, R. G., Mah, E. (2007). Grape seed extract inhibits lipid oxidation in muscle from different species during refrigerated and frozen storage and oxidation catalyzed by peroxynitrite and iron/ascorbate in a pyrogallol red model system. Meat Sci., 77, 540-546.

Cheng, J. H., Wang, S. T., Ockerman, H. W. (2007). Lipid oxidation and color change of salted pork patties. Meat Sci., 75, 71-77.

Das, A. K., Anjaneyulu, A. S. R., Biswas, S. (2006). Effect of carnosine preblending on the quality of ground buffalo meat. Food Chem., 97, 531-538.

Djenane, D., Martínez, L., Escalante, A. S., Beltrán, J. A. Roncalés, P. (2004). Antioxidant effect of carnosine and carnitine in fresh beef steaks stored under modified atmosphere. Food Chem., 85, 453-459.

Falowo, A. B., Fayemi, P. O., Muchenje, V. (2014). Natural antioxidants against lipid-protein oxidative deterioration in meat and meat products: A review. Food Res. Int., 64, 171-181.

Faustman, C., Sun, Q., Mancini, R., Suman, S. P. (2010). Myoglobin and lipid oxidation interactions: Mechanistic bases and control. Meat Sci., 86, 86-94.

Garrido, M. D., Auqui, M., Martí, N., Linares, M. B. (2011). Effect of two different red grape pomace extracts obtained under different extraction systems on meat quality of pork burgers. LWT-Food Sci. Technol., 44, 2238-2243.

Grunwald, E. W., Richards, M. P. (2006). Studies with Myoglobin variants indicate that released hemin is the primary promoter of lipid oxidation in washed fish muscle. J. Agr. Food Chem., 54, 4452-4460.

Hayes, J. E., Stepanyan, V., Allen, P., O’Grady, M. N., O'Brien, N. M., Kerry, J. P. (2009). The effect of lutein, sesamol, ellagic acid and olive leaf extract on lipid oxidation and oxymyoglobin oxidation in bovine and porcine muscle model systems. Meat Sci., 83, 201-208.

Received - Przyjęto: 9.06.2014

For citation - Do cytowania
Jose, C. (2011). Anti- and pro-oxidant interactions with myoglobin in lamb meat, and the influence on color stability. (PhD thesis). Murdoch University.

Kim, S., Min, S. C., Shin, H., Lee, Y., Cho, A. R., Kim, S. Y., Han, J. (2013). Evaluation of the antioxidant activities and nutritional properties of ten edible plant extracts and their application to fresh ground beef. Meat Sci., 93, $715-722$.

Krzywicki, K. (1982). The determination of heam pigments in meat. Meat Sci., 7, 29-35.

Lorenzo, J. M., Sineiro, J., Amado, I. R., Franco, D. (2014). Influence of natural extracts on the shelf life of modified atmosphere-packaged pork patties. Meat Sci., 96, 526-534.

Liu, F., Dai, R., Zhu, J., Li, X. (2010). Optimizing color and lipid stability of beef patties with a mixture design incorporating with tea catechins, carnosine, and $\alpha$-tocopherol. J. Food Eng., 98(2), 170.

Mielnik, M. B., Olsen, E., Vogt, G., Adeline, D., Skrede, G. (2006). Grape seed extract as antioxidant in cooked, cold stored turkey meat. LWT-Food Sci. Technol., 39, 3, 191-198.

Mikkelsen, A., Juncher, D., Skibsted, L. H. (1999). Metmyoglobin reductase activity in porcine $m$. longissimus dorsi muscle. Meat Sci., 51, 2, 155-161.

Pong, C.-Y., Chiou, T.-K., Nieh, F.-P., Jiang, S.-T. (2000a). Purification and characterization of metmyglobin reductase from ordinary musle of blue-fin tuna. Fisheries Sci., 66, 599-604.

Ripoll, G., Joy, M., Muñoz, F. (2011). Use of dietary vitamin $\mathrm{E}$ and selenium (Se) to increase the shelf life of modified atmosphere packaged light lamb meat. Meat Sci., 87, 88-93.

Suman, S. P., Hunt, M. C., Nair, M. N., Rentfrow, G. (2014). Improving beef color stability: Practical strategies and underlying mechanisms. Meat Sci., 98, 490-504.

Shah, M. A., Bosco, S. J. D., Mir, S. A. (2014). Plant extracts as natural antioxidants in meat and meat products. Meat Sci., 98, 21-33.

Tang, S. Z., Kerry, J. P., Sheehan, D., Buckley, D. J. (2001a). A comparative study of tea catechins and $\alpha$-tocopherol as antioxidants in cooked beef and chicken meat. Eur. Food Res. Technol., 213, 286-289.

Tang, S. Z., Kerry, J. P., Sheehan, D., Buckley, D. J. (2002). Antioxidative mechanisms of tea catechins in chicken meat systems. Food Chem., 76, 45-51.

Accepted for print - Zaakceptowano do druku: 16.10.2014

Liu, F., Xu, Q., Dai, R., Ni, Y. (2015). Effects of natural antioxidants on colour stability, lipid oxidation and metmyoglobin reducing activity in raw beef patties. Acta Sci. Pol. Technol. Aliment., 14(1), 37-44. DOI: 10.17306/J.AFS.2015.1.4 